\title{
Medemens als medicijn
}

\section{Beter contact met iemand met dementie}

\section{$\mathrm{Na}$ de} van de coronacrisis mogen we weer op bezoek in het verpleeghuis. Maar wat zeg je na zo lange tijd? En wat kun je doen om het contact met mensen met dementie zo goed mogelijk te laten verlopen zodat het een maximale positieve impact heeft? Uit communicatieonderzoek kunnen we heel wat leren over de juiste woorden en gebaren, stelt Kasper Bormans (KULeuven). Hoe kunnen we deze kennis toepassen in ons hernieuwde contact met ouderen?

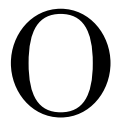

p het moment van schrijven, half juli, bevinden we ons in een soort schemerfase waarin de lockdown in de verpleeghuiszorg steeds verder wordt versoepeld. $\mathrm{Na}$ een totale bezoekstop van zo'n drie maanden mogen verpleeghuisbewoners al weer enige tijd beperkt bezoek ontvangen, al zijn er nog grote verschillende tussen de huizen. Vooropgesteld dat een tweede coronagolf uitblijft zullen we steeds verdere verruimingen zien. Maar wat zullen de gevolgen zijn van de lockdown en het 'nieuwe normaal' voor kwetsbare ouderen en hun naasten?

We naderen elkaar fysiek tot op anderhalve meter, maar hoe ver voelen we ons mentaal van elkaar verwijderd? Corona zorgt voor een golf van eenzaamheid en onbegrip, zowel bij ouderen als bij hun bezorgde familie en vrienden. De afgelopen maanden vroeg het coronavirus alle aandacht, maar ook dementie is in de visie van de Wereldgezondheidsorganisatie (WHO) een absolute topprioriteit. En beide aandoeningen intensiveren elkaars negatieve impact. De parallel tussen beide is dat in afwachting van de 'wonderpil' voor dementie of het magische vaccin voor COVID-19, de medemens voorlopig het voornaamste medicijn kan zijn.

Hoe kun je elementen als eigenaarschap, positiviteit en toekomstperspectief binnenbrengen in de leefwereld van de ander, zelfs met ontsmette handen vanachter plexiglas? In het onderstaande richten we ons specifiek op mensen met dementie, maar de adviezen zijn van toepassing op al onze contacten met oudere mensen in de zorg.

\section{CONTROLE TERUGGEVEN}

Mensen met dementie worden geleidelijk aan afhankelijker van anderen. De aandoening maakt het moeilijker keuzes te maken en de nabije omgeving neemt iemand met dementie allerlei dagelijkse activiteiten uit handen. De oudere met dementie heeft minder controlegevoel en daardoor neemt diens levenskwaliteit af. Corona heeft daar een schepje bovenop gedaan doordat verpleeghuisbewoners plots volledig afgesloten werden van de buitenwereld en bijkomende en vaak moeilijk uit te leggen regels kregen opgelegd. Een tegenbeweging is dan ook noodzakelijk. Voor het fysiek en mentaal welbevinden van verpleeghuisbewoners zou het goed zijn als hulpverleners hen, voor zover mogelijk, inspraak zouden laten hebben in hoe bezoek verloopt. Bijvoorbeeld wat betreft het aanvangstijdstip of de stoel waarin men wil gaan zitten. En bezoekers zouden tijdens het gesprek doelbewust kunnen vragen naar zaken waarover de ander wél (een zekere mate van) controle kan uitoefenen. In een openingsvraag als 
Tijd maken voor mensen met dementie 52 manieren communiceren

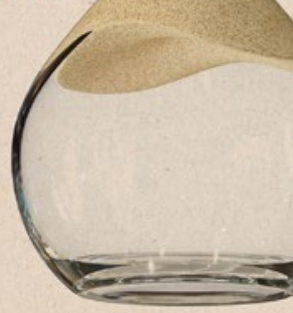

LANNOO

'Hoe is het?' of 'Alles goed?' ontbreekt een persoon en dat kan de ander herleiden tot een passieve ontvanger van impulsen. Een betere startvraag is bijvoorbeeld: 'Wat heb je vandaag gedaan?', omdat je dan de gesprekspartner het gevoel teruggeeft eigenaar te zijn van zijn handelen. Verder kan de bezoeker proberen op te treden als een spiegel en subtiel de woorden en lichaamshouding van de ander weerkaatsen. Herhaal woorden en zinnen en neem gebaren en gelaatsuitdrukkingen over. Dergelijke eenvoudige dingen kunnen het zelfbeeld van je gesprekspartner versterken. We zien pas wie we zelf zijn, in het gelaat van de ander.

\section{RUIMTE VOOR IETS POSITIEFS}

Ouderdom en dementie worden in de publieke sfeer voornamelijk geassocieerd met negatieve concepten als verdriet, verlies en achteruitgang. Bedenk zelf maar: wat is de laatste keer dat je nog eens iets positiefs over dementie hebt gehoord? Corona heeft aan de leefwereld van mensen met dementie een extra dosis negativiteit toegevoegd door de weinige overblijvende aange- name impulsen, zoals warm menselijk contact of verhalen delen en daar samen om lachen, weg te kapen. Het is echter belangrijk een gezond evenwicht te bewaren en om zonder de zwaarte van de aandoening te ontkennen, ook de positieve aspecten een plaats te geven. Hulpverleners en mantelzorgers spelen in het binnenbrengen van positiviteit een levensnoodzakelijke rol. Maar doe je dat? Humor bijvoorbeeld is een belangrijk element, maar dan wel als het daarbij om méér gaat dan het vertellen van een flauwe grap. Humor gebruik je om op een andere manier naar dezelfde werkelijkheid te kijken, zodat het mogelijk wordt om te relativeren ('Neen, die alcoholgel kan je helaas niet opdrinken!'). Ook belangrijk is het vermogen om de eenzijdige blik vanuit tekortkomingen ('We kunnen elkaar niet vastpakken!') om te buigen naar mogelijkheden ('Je hebt leren Skypen!'). In een gesprek kun je verder doelbewust op zoek gaan naar iets positiefs aan de ander om dat vervolgens onder woorden te brengen. Op die manier plak je een 'positief etiket' op iemands voorhoofd en vergroot je de waarschijnlijkheid dat hij zich ernaar zal gedragen ('Je moet doorzetten!' is dwingend, maar 'Jij bent een echte doorzetter!' is een oprechte aanmoediging). Heb het niet enkel over hoe erg het allemaal is met die corona en wie er allemaal is overleden, maar deel ook jouw eigen grappige ervaringen en stuntelige momenten. Toegeven dat jij ook een keer per ongeluk je mondmasker achterstevoren had opgezet, maakt je kwetsbaar en plaatst je in een vergelijkbare positie als een zorgontvanger die door zijn aandoening toch al vaak het gevoel zal hebben onhandig te zijn of tekort te schieten.

\section{TOEKOMSTBEELD}

Ouderdom en dementie gaan niet alleen samen met geheugenverlies, maar ook met een verlies van toekomstperspectief. Mensen met minder herinneringen hebben ook minder vooruitzichten. Zij worden vaak enkel benaderd vanuit de voorbije tijd ('reminisceren') en onbewust beroofd van enig perspectief op de toekomst. Nochtans is het cruciaal voor het menselijk welbevinden iets te hebben om naar uit te kijken. Positieve toekomstscenario's vormen een beweegreden om 's morgens op te staan. COVID-19 berooft ons allemaal van allerlei positieve toekomstscenario's. Denk maar aan topatleten die gewoon zijn zich doelen te stellen maar plots afhaken omdat de coronapandemie hun concrete richtpunten, zoals deelname aan de Olympische Spelen, afneemt. Ook mensen in verpleeghuizen werden ineens geconfronteerd met nieuwe onzekerheden: 'Wanneer mogen we onze kamer uit?', 'Wanneer mogen we onze kleinkinderen weer omarmen?'

In een gesprek kan het daarom betekenisvol zijn niet enkel in de verleden tijd te blijven hangen, maar ook de sprong voorwaarts te maken. Je kunt de voorbije eigenaardigheden van de coronacrisis ('Die nooit geziene lege straten') als vertrekpunt gebruiken naar een hoopvollere blik op de toekomst ('Sommige landen zijn hun grenzen opnieuw aan het openen!'). Begin bij de nabije toekomst, die start vandaag. En kies ervoor je gesprek af te ronden met een cliffhanger, iets aangenaams in de nabije toekomst, waardoor je de ander weer een reden geeft om ergens naar uit te kijken. Zeg niet: 'Ik ga nu naar huis', maar: 'Tot volgende zondag!'

\footnotetext{
TEKST KASPER BORMANS

Dr. Kasper Bormans doctoreerde onder

supervisie van psychiater Dirk De Wachter en is verbonden aan de Leuven School for Mass Communication Research; hij is auteur van het boek Wat Alz?, bedenker van 'Het Spel van de Verbeelding' en ontwikkelaar van de mobiele applicatie MemoryHome. In september verschijnt van hem bij Uitgeverij Lannoo Tijd maken voor mensen met dementie. 52 manieren om te blijven communiceren.
} 